\title{
MOBILNOŚĆ W CENTRUM ŚREDNIEGO MIASTA W PERSPEKTYWIE MOŻLIWOŚCI WPROWADZENIA STREFY PŁATNEGO PARKOWANIA - STUDIUM PRZYPADKU TCZEWA
}

\section{Mobility in the centre of a medium-sized city in the perspective of the prospective introduction of a paid parking zone - a case study of Tczew}

\section{Michał Adam Kwiatkowski (1), Grzegorz Pawlikowski (2), Jadwiga Biegańska (3), Donata Wysocka (4)}

(1) Katedra Studiów Miejskich i Rozwoju Regionalnego, Wydział Nauk o Ziemi i Gospodarki Przestrzennej, Uniwersytet Mikołaja Kopernika w Toruniu, Lwowska 1, 87-100 Toruń

e-mail: kwiat@umk.pl

(iD) https://orcid.org/0000-0002-4708-7508

(2) Samodzielne stanowisko ds. polityki rowerowej, Urząd Miejski w Tczewie, PI. Marszałka Piłsudskiego 1, 83-110 Tczew

e-mail: rowery@um.tczew.pl

(3) Katedra Studiów Miejskich i Rozwoju Regionalnego, Wydział Nauk o Ziemi i Gospodarki Przestrzennej, Uniwersytet Mikołaja Kopernika w Toruniu, Lwowska 1, 87-100 Toruń

e-mail: jadwigab@umk.pl

(iD) https://orcid.org/0000-0002-0586-089X

(4) Katedra Studiów Miejskich i Rozwoju Regionalnego, Wydział Nauk o Ziemi i Gospodarki Przestrzennej, Uniwersytet Mikołaja Kopernika w Toruniu, Lwowska 1, 87-100 Toruń

e-mail: 293788@stud.umk.pl

\section{Cytacja:}

Kwiatkowski M. A., Pawlikowski G., Biegańska J., Wysocka D., 2021, Mobilność w centrum średniego miasta w perspektywie możliwości wprowadzenia strefy płatnego parkowania - studium przypadku Tczewa, Prace Komisji Geografii Komunikacji PTG, 24(3), 36-48.

Streszczenie: Polityka parkingowa należy do ważniejszych wyzwań w rozwoju współczesnych miast w zakresie transportu. Jednym z narzędzi kształtowania tego zjawiska w miastach jest wprowadzanie stref płatnego parkowania, które mają zwiększać rotację pojazdów oraz zachęcać do korzystania z innych środków transportu w codziennych dojazdach. Jest to szczególnie ważne w kontekście centrów miast. Wdrażanie stref płatnego parkowania stanowi często stosowane rozwiązanie w dużych miastach, rzadziej w średnich i małych. Celem tego badania jest analiza sposobu docierania mieszkańców średniego miasta Tczewa - do centrum (Starego Miasta) oraz ocena możliwości wprowadzenia strefy płatnego parkowania. Badanie przeprowadzono metodą ankiety, posługując się techniką PAPI (Paper and Pencil Interview), w którym zebrano 375 odpowiedzi. W przeprowadzonym badaniu ankietowym wykazano, że istnieje duży poziom akceptacji społecznej dla możliwości wprowadzenia strefy płatnego parkowania w analizowanym przypadku. W badaniu wykazano ponadto, że znaczną większość użytkowników centrum stanowią osoby docierające tam pieszo. Potwierdzono także, że mieszkańcy są skłonni nie tylko zapłacić za parkowanie w centrum miasta, ale także przejść pewien dystans pieszo od miejsca postojowego do celu podróży. Niniejsza praca może mieć charakter aplikacyjny i stanowić wskazówkę dla innych miast o podobnej wielkości i strukturze, które zamierzają wprowadzić strefę płatnego parkowania lub innego rodzaju ograniczenia ruchu samochodów.

Słowa kluczowe: mobilność, polityka parkingowa, przestrzeń miejska, średnie miasto, Tczew 


\begin{abstract}
Parking policy is one of the more important challenges in the development of modern cities in terms of transport. One of the tools for shaping this policy in cities is the introduction of paid parking zones, which are intended to increase vehicle turnover and encourage the use of other means of transport for everyday commuting. This is particularly important in the context of city centres. The introduction of paid parking zones is a common solution in large cities, less so in medium-sized and small ones. The aim of this study is to analyse how residents of a medium-sized city - Tczew - travel to the centre (Old Town) and to assess the possibility of introducing a paid parking zone. The study was carried out through a survey, using the PAPI (Paper and Pencil Interview) technique, with 375 responses collected. It showed that there is a high level of public acceptance for the possible introduction of a paid parking zone in the case under consideration. The study also yielded that the vast majority of users of the centre are people who get there on foot. It was also confirmed that residents are not only willing to pay for parking in the city centre, but also to walk a certain distance from their parking space to their destination. This work can be applied as a guide to other cities of similar size and structure that intend to introduce paid parking zones or other types of car traffic restrictions.
\end{abstract}

Keywords: mobility, parking policy, urban space, medium-sized city, Tczew

\section{Wstęp}

Transport, szczególnie w miastach, od lat stanowi przedmiot zainteresowania decydentów i planistów tego aspektu życia w mieście. Zwiększający się poziom motoryzacji sprawia, że transport coraz bardziej oddziałuje na codzienne życie mieszkańców miast. Problem ten przejawia się głównie tym, że coraz większa liczba mieszkańców miast nie uznaje podróży miejskich, nawet tych najkrótszych, bez wykorzystania samochodu. Negatywne skutki tej postawy można odczuć przede wszystkim przez coraz częściej tworzące się korki w miastach oraz rosnące zanieczyszczenie środowiska przez transport. Coraz bardziej istotny problem stanowi też znalezienie miejsc do parkowania samochodu. Przestrzeń miejska, także w polskich miastach, jest przepełniona samochodami, a każdorazowe interwencje miast w zwiększanie liczby miejsc postojowych nie przynoszą skutku i nadal nie zaspokajają stale rosnących potrzeb. Zwiększanie liczby miejsc postojowych jest także bardzo często równoznaczne z likwidacją przestrzeni przeznaczonej dla innych użytkowników. Najczęściej dotyczy to przestrzeni zieleni miejskiej lub przestrzeni użytkowanej przez innych uczestników ruchu.

Najczęściej dyskutowaną kwestią w zakresie miejskiej polityki parkingowej jest tworzenie miejsc do parkowania w centrach miast, szczególnie na ich obszarach historycznych i zabytkowych. W sposób oczywisty centra miast generują największe zainteresowanie i właśnie tam krzyżują się najważniejsze trasy podróży, zarówno mieszkańców, jak i przyjezdnych. Dlatego wiele miast, ze względu na limit dostępnej dla ruchu przestrzeni, wprowadziło ograniczenia w ruchu pojazdów i opłaty za parkowanie w centrum, mając na celu zwiększenie rotacji samochodów poprzez wymuszenie krótszego czasu parkowania, lub przekonanie mieszkańców do dojazdu innym środkiem transportu. Istotnym problemem, który generuje ruch samocho- dowy w zabytkowych centrach miast jest także ich estetyka i funkcja, którą pełnią dla mieszkańców. Zbyt duża liczba miejsc postojowych oraz ulice udostępnione dla ruchu kołowego na starówkach ograniczają rozwój funkcji wypoczynkowych i rekreacyjnych tych miejsc. Wpływają także negatywnie na ich atrakcyjność i poczucie bezpieczeństwa. O ile w największych miastach problemy te częściowo zostały rozwiązane poprzez wprowadzenie stref płatnego parkowania, tak w małych i średnich miastach ${ }^{1}$ dostęp do centrów, często zabytkowych, pozostaje nadal nieograniczony lub ograniczony tylko w niewielkim stopniu. Problem, który istnieje w małych i średnich miastach wydaje się być wart szczególnej uwagi, ze względu na ich wielkość i zwarty charakter przestrzenny. Nieduże odległości w małych i średnich miastach skłaniają do postawienia pytania, czy przemieszczanie w takiej przestrzeni zawsze wymaga korzystania z samochodu - dobrą alternatywą w tym zakresie może być dojazd rowerem lub dotarcie pieszo. Wspomniany jednak wcześniej wysoki poziom motoryzacji, zwłaszcza w Polsce, sprawia, że duża liczba mieszkańców, także w małych i średnich miastach, decyduje się korzystać z samochodu jako podstawowego środka transportu nawet na krótkich dystansach. Wprowadzenie strefy płatnego parkowania lub ograniczenie ruchu w centrum wydaje się być w związku z tym decyzją trudną politycznie, na którą niechętnie decydują się samorządy. Podjęciu takiej decyzji towarzyszy także obawa, że ograniczenie możliwości dojazdu samochodem do centrum może mieć działanie destrukcyjne dla gospodarki tej części

\footnotetext{
Klasyfikację miast według ich wielkości ustalono na podstawie opracowań D. Szymańskiej (2013) i S. Środy-Murawskiej (2019), w których zaproponowano, aby za miasto małe przyjmować jednostkę osadniczą o wielkości do 20 tys. mieszkańców, miasto średnie - od 20 do 100 tys. mieszkańców, a miasto duże - powyżej 100 tys. mieszkańców.
} 
miasta oraz negatywnie odbić się na zainteresowaniu mieszkańców tym obszarem. Proces wdrożenia strefy płatnego parkowania w małych i średnich miastach może stanowić zatem interesujący przedmiot badania, które pozwoliłoby zweryfikować, jak użytkowana jest przestrzeń centrum takiego miasta i jakie są oczekiwania jej użytkowników.

Jak uzasadniono w uchwale rady miejskiej Tczewa dotyczącej utworzenia strefy, najważniejszym celem tego działania było zapewnienie rotacji samochodów i zwiększenia w ten sposób dostępności miejsc parkingowych w centrum miasta. Zaobserwowano bowiem długotrwałe pozostawianie samochodów na parkingach w Tczewie, co z kolei uniemożliwiało przyjazd i pozostawienie samochodu mieszkańcom miasta i osobom przyjezdnym, które docierały do centrum w celu szybkiego załatwienia swoich spraw. Sytuacja prowadziła także do tego, że samochody były pozostawiane również w miejscach do tego nieprzeznaczonych. Zgodnie z inicjatywą Prezydenta Miasta, w październiku 2021 r. pod obrady Rady Miejskiej trafiła uchwała, mająca rozwiązać te problemy.

\section{Cel pracy i metody}

Celem pracy jest analiza sposobu docierania mieszkańców średniego miasta - Tczewa - do centrum (Starego Miasta) oraz ocena możliwości wprowadzenia strefy płatnego parkowania.

Dla realizacji celu opracowania w badaniu postawiono następujące pytania badawcze:

- W jakim celu i w jaki sposób mieszkańcy Tczewa i osoby spoza miasta docierają na Stare Miasto?

- Jakie ograniczenia w ruchu lub parkowaniu samochodów są gotowi zaakceptować mieszkańcy i osoby korzystające z przestrzeni Starego Miasta?

- Czy ograniczenie ruchu lub parkowania samochodów w przestrzeni Starego Miasta w Tczewie może negatywnie oddziaływać na gospodarkę i lokalne przedsiębiorstwa funkcjonujące w tym miejscu?

W badaniu posłużono się przykładem średniego miasta, mając na uwadze specyfikę takiej przestrzeni i możliwości łatwiejszego oraz szybszego niż w dużych miastach dotarcia do celu przy użyciu innych niż samochód środków transportu. Przeprowadzone badanie ma także walor aplikacyjny, a uzyskane wyniki mogą mieć szerokie zastosowanie. W ramach pracy uzyskano wartościowy, z punktu widzenia decydentów, zbiór informacji o zachowaniach i oczekiwaniach mieszkańców pod względem sposobu i możliwości dotarcia do centrum miasta. Wyniki te mogą być pomocne i stać się cenną wskazówką przy planowaniu zmian mających wyeliminować lub znacząco ograniczyć ruch samochodowy w centrach, szczególnie małych i średnich miast.
Zaproponowany cel opracowania, skoncentrowany wokół percepcji przestrzeni miejskiej, wymagał zastosowania odpowiednich metod i technik badawczych. Starając się poznać opinie względnie dużej grupy użytkowników centralnej części Tczewa, tj. Starego Miasta, zdecydowano się na metody badań ilościowych, które pozwalają zebrać znaczną ilość informacji o dużym stopniu standaryzacji. Zwłaszcza ta ostatnia cecha, tj. stopień standaryzacji, powoduje, że zebrany materiał badawczy można dość łatwo porównywać, co było istotne zważywszy na podjętą problematykę. Spośród wielu metod badań ilościowych w opracowaniu zastosowano sondaż posługując się techniką PAPI (Paper and Pencil Interview). Arkusz ankiety składał się z 10 pytań, w tym metryczki. Samo badanie zostało przeprowadzone w dniach 6-7 października $2021 \mathrm{r}$. w godz. 10.00-12.00 oraz 13.00-15.00 w Tczewie. Badanie prowadzono w warunkach: pierwszego dnia zachmurzenie i przelotne opady deszczu, temperatura w granicach 16-17 stopni Celsjusza, drugiego dnia słonecznie, temperatura w granicach 12-13 stopni Celsjusza. Badanie wykonali, na Starym Mieście na ulicach: Dąbrowskiego, Mickiewicza, Krótkiej oraz na PI. Hallera i przyległych do niego uliczkach, pracownicy Urzędu Miejskiego w Tczewie oraz wolontariusze i wolontariuszki Zespołu Szkół Budowlanych i Odzieżowych w Tczewie, przy wsparciu merytorycznym Wydziału Nauk o Ziemi i Gospodarki Przestrzennej Uniwersytetu Mikołaja Kopernika w Toruniu. W badaniu łącznie uczestniczyło 17 przeszkolonych ankieterów. Zgromadzony w kontakcie bezpośrednim z respondentami materiał badawczy obejmował 375 ankiet, przy czym dwie wyeliminowano ze względu na braki danych. Wyniki badań ankietowych zakodowano i wprowadzono do systemu LimeSurvey. Dalsze zestawienia i analizy przygotowano w oprogramowaniu PS Imago.

Dokonując krótkiej charakterystyki społeczno-demograficznej badanych, należy podkreślić, iż spośród wszystkich rozpatrzonych opinii na temat strefy płatnego parkowania na obszarze Starego Miasta w Tczewie, 67,0\% zostało wyrażonych przez kobiety a 33,0\% przez mężczyzn. Za szczególnie istotne uznano jednak miejsce zamieszkania, starając się zapewnić względnie porównywalny udział mieszkańców Tczewa, zarówno tych, którzy mieszkają na Starym Mieście, jak i poza zespołem staromiejskim. W rezultacie w badaniu wzięło udział $40,6 \%$ mieszkańców deklarujących jako miejsce zamieszkania Stare Miasto oraz 37,4\% mieszkańców deklarujących zamieszkiwanie poza zespołem staromiejskim. Ponadto, 21,9\% respondentów stanowiły osoby, które mieszkają poza Tczewem, a które korzystały w dniu badania z przestrzeni Starego Miasta. 


\section{Przegląd literatury}

Wprowadzenie strefy płatnego parkowania jest jednym z narzędzi szerszych działań miast, realizowanych w ramach tzw. polityk parkingowych (Marsden, 2006; Mingardo i in., 2015; Yan i in., 2019). Realizacja tego działania w centralnej części miasta ma za zadanie zwiększyć rotację samochodów na tym obszarze oraz zachęcić do korzystania z innych form transportu w dojazdach do centrum (Shoup, 2005; Brzeziński, Dybicz, 2013; Sklorz, 2013). Zwiększająca się rotacja ma z kolei zmniejszyć zjawisko ruchu samochodów poszukujących miejsc postojowych (Duda-Wiertel, Szarata, 2019). Zwiększająca się w czasie cena za każdą kolejną godzinę parkowania jest skutecznym narzędziem do wymuszania na kierowcach krótszego zajmowania miejsc parkingowych, co w rezultacie umożliwia większej liczbie osób skorzystanie z parkingu, a docelowo $z$ oferty przestrzeni centrum miasta. Wprowadzenie strefy płatnego parkowania może zatem przynieść korzyści w postaci zwiększenia dostępności obszaru dla większej liczby użytkowników. Może się także przyczynić do zmniejszenia zainteresowania dojazdami do centrum samochodem na rzecz innych, alternatywnych i zrównoważonych środków transportu (Kiciński, Żmuda-Trzebiatowski, 2018), takich, które w mniejszym stopniu wpływają na zapełnienie i estetykę przestrzeni (Rietveld, Koetse, 2008; Sklorz, 2013).

Centra miast wypełniają zazwyczaj liczne funkcje, w tym przede wszystkim mieszkaniowe, administracyjne, reprezentacyjne, rekreacyjne, kulturowe, ale także handlowo-usługowe (Scheiner i in., 2020). W zakresie ostatniej z wymienionych funkcji, wprowadzenie strefy płatnego parkowania w centralnej części miasta może wzbudzić obawy o dalszą kondycję finansową działających w tej przestrzeni przedsiębiorców i usługodawców. Dominuje przekonanie, że wprowadzenie ograniczeń w możliwości parkowania samochodów przyczyni się do zmniejszenia liczby klientów i interesantów działalności gospodarczych prowadzonych w centrum (Sztabinski, 2009; Rietveld, Koetse, 2008). W tym zakresie bardzo ważnym aspektem jest sprawdzanie skłonności kierowców do płacenia za miejsca postojowe (Ardeshiri i in., 2021). Doświadczenia miast, szczególnie największych, pokazują, że istnieją różne graniczne kwoty, jakie użytkownicy parkingów są w stanie zapłacić za parkowanie (van Ommeren i in., 2011). Wynikają one przede wszystkim z czynników społecznych, ekonomicznych, czy też odległości, którą muszą pokonać pieszo od miejsca pozostawienia samochodu do celu podróży. Jak jednak wykazały badania prowadzone w dużych miastach, doświadczenie zatłoczenia parkingu i braku dostępnych miejsc istotnie wpływa na akceptację płatnego parkowania (Guo, McDonnell, 2013).
Według badań Rietvelda i in. (2002), wprowadzenie stref płatnego parkowania nie musi powodować odpływu klientów sklepów i punktów usługowych na tym obszarze. Obawy te opierają się zwykle na błędnym założeniu, że z oferty centrum miasta korzystają wyłącznie lub w dużej mierze tylko osoby, które docierają tam samochodem. Całkowicie niedoceniony pozostaje potencjał klientów przybywających do centrum pieszo, rowerem lub środkami komunikacji zbiorowej. Wyniki badań Arancibia i in., 2019 oraz von Schneidemessera i Betziena (2021) wskazują, że dostosowanie przestrzeni do potrzeb innych niż kierowcy uczestników ruchu wpływa pozytywnie na zyski lokalnych przedsiębiorców. Wprowadzenie stref płatnego parkowania oraz ograniczanie ruchu kołowego w centrach miast wydaje się być zatem słusznym posunięciem nie tylko $w$ kontekście poprawy estetyki tej przestrzeni, ale przede wszystkim dla wytworzenia lepszych warunków do jazdy na rowerze oraz przemieszczania się pieszo. Potencjał ten wydaje się być szczególnie istotny w małych i średnich miastach, w których dystanse do pokonania zarówno między osiedlami a centrum i w samym centrum są możliwe do przebycia pieszo lub rowerem bez większego wysiłku, kosztu i czasu podróży.

\section{Obszar badań}

Miasto Tczew jest położone w północnej części powiatu tczewskiego i w południowo-wschodniej części województwa pomorskiego. Obszar miasta wynoszący $22,4 \mathrm{~km}^{2}$ (wg stanu na dzień 1 stycznia 2021 r.), zamieszkuje 55702 osób, w tym 54579 na pobyt stały i 1123 na pobyt czasowy (Urząd Miejski w Tczewie, 2021a). Tczew jest miastem o relatywnie wysokiej gęstości zaludnienia wynoszącej 2486,7 osób/ $/ \mathrm{km}^{2}$ (Urząd Miejski w Tczewie, 2021b). Najbardziej odległe punkty sieci osiedleńczej nie leżą od siebie dalej niż $5 \mathrm{~km}$. Żaden punkt miasta nie leży też od stacji kolejowej dalej niż $3,5 \mathrm{~km}$, co daje duży potencjał rozwoju aktywnych form mobilności i nie wymaga korzystania z samochodu w codziennych dojazdach.

Tczew jest położony w obrębie obszaru metropolitalnego Gdańsk-Gdynia-Sopot, który poza Trójmiastem (stanowiącym centrum aglomeracji), tworzą ośrodki regionalne - Tczew i Wejherowo - oraz silne ośrodki lokalne: Pruszcz Gdański, Rumia, Reda i sąsiednie gminy wiejskie. Najbliżej położonymi od Tczewa ważniejszymi ośrodkami miejskimi są Gdańsk (32km), Gdynia (55 km) i Elbląg (52 km). Przez miasto prowadzi droga krajowa nr 91 Gdańsk-Toruń i droga wojewódzka nr 224. W sąsiedztwie Tczewa przebiega autostrada A1 (węzeł Stanisławie) oraz droga krajowa $\mathrm{nr} 22$.

W Tczewie w 2020 r. zarejestrowanych było 28412 samochodów (samochody osobowe, ciężarowe, spe- 
cjalne i sanitarne bez ciągników, przyczep i naczep). Poziom motoryzacji w 2020 r. wynosił 510 samochodów ogółem na 1000 mieszkańców (ryc. 1). W ciągu ostatnich 15 lat, liczba samochodów zwiększyła się 2,5-krotnie. Od 2014 r. średnio co roku przybywa ok. 1000 samochodów (Urząd Miejski w Tczewie: Tczew Miasto dla Rowerów, 2020).
Zgodnie z projektem uchwały Rady Miejskiej w Tczewie z dnia 15.10.2021 r. w sprawie strefy płatnego parkowania na terenie Gminy Miejskiej Tczew oraz wysokości stawek opłat za parkowanie, wysokości opłaty dodatkowej i sposobu ich pobierania, planuje się wprowadzenie stref płatnego parkowania w 29 lokalizacjach miasta, w tym głównie na obszarze ścisłego

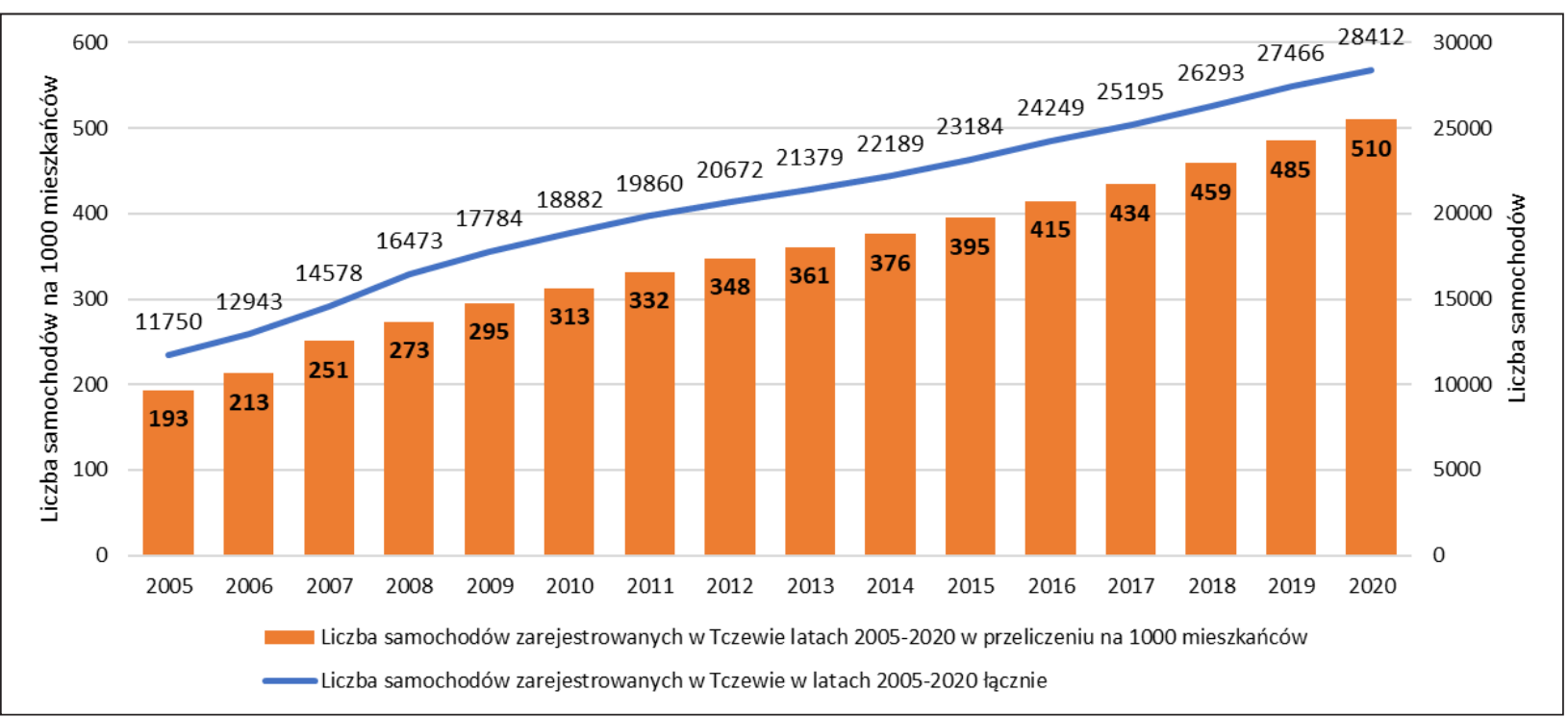

Ryc. 1. Liczba samochodów zarejestrowanych w Tczewie w latach 2005-2020 łącznie i w przeliczeniu na 1000 mieszkańców.

Źródło: Urząd Miejski w Tczewie: Tczew - Miasto dla Rowerów, 2020.

Na obszarze Starego Miasta funkcjonuje strefa uspokojonego ruchu o maksymalnej dopuszczalnej prędkości $30 \mathrm{~km} / \mathrm{h}$. Wprowadzenie strefy było połączone $\mathrm{z}$ rewitalizacją przestrzeni publicznych oraz udostępnianiem ruchu rowerowego pod prąd (tzw. kontraruchu rowerowego). Strefy uspokojonego ruchu zmniejszają liczbę oraz dotkliwość wypadków drogowych, pozytywnie wpływają na jakość powietrza, jak i na rozwój ruchu pieszego oraz rowerowego.

Obszar Starego Miasta ograniczony jest od strony północnej i zachodniej linią kolejową, od wschodu rzeką Wisłą, na południu granicę stanowi Park Miejski. Obszar obejmuje *historyczne centrum miasta, objęte wpisem do rejestru zabytków, otoczone przez historyczne przedmieścia - po stronie zachodniej część Przedmieścia Berlińskiego, po stronie północnej Przedmieście Dworcowe, od południa Przedmieście Królewieckie. Stare Miasto zajmuje powierzchnię 91 ha i jest zamieszkiwane przez 7488 osób. Obszar ten charakteryzuje się stosunkowo dużą gęstością zaludnienia, co jest cechą charakterystyczną dla obszarów śródmiejskich.
Starego Miasta w Tczewie (m.in. ulice Dąbrowskiego, Kościuszki, Wyszyńskiego, Słowackiego, Ściegiennego, Łazienna, Pl. Hallera) (ryc. 2). Planowana strefa ma mieć charakter wyspowy, z jedną dużą częścią o charakterze ciągłym i mniejszymi, niepołączonymi obszarami.

Zgodnie z założeniami regulaminu, strefa ma funkcjonować $w$ dni powszednie od poniedziałku do piątku w godz. od 8.00 do 17.00, z wyłączeniem dni ustawowo wolnych od pracy. Stawka za 1 godz. parkowania ma wynosić 2 zł, a w przypadku osoby posiadającej kartę mieszkańca 1 zł.

Planowane wprowadzenie strefy płatnego parkowania skłania zatem do analizy dwóch zasadniczych aspektów. Po pierwsze, zakładając wysoki wskaźnik motoryzacji, zasadne wydaje się sprawdzenie, w jaki sposób mieszkańcy docierają do centrum miasta. Po drugie, należałoby również ustalić, jak kształtuje się postrzeganie możliwości wprowadzenia strefy płatnego parkowania. Oba te aspekty mogą stanowić praktyczną wskazówkę w zakresie kształtowania obszaru strefy oraz jej cennika dla władz tego miasta oraz innych miast o podobnej strukturze i wielkości. 


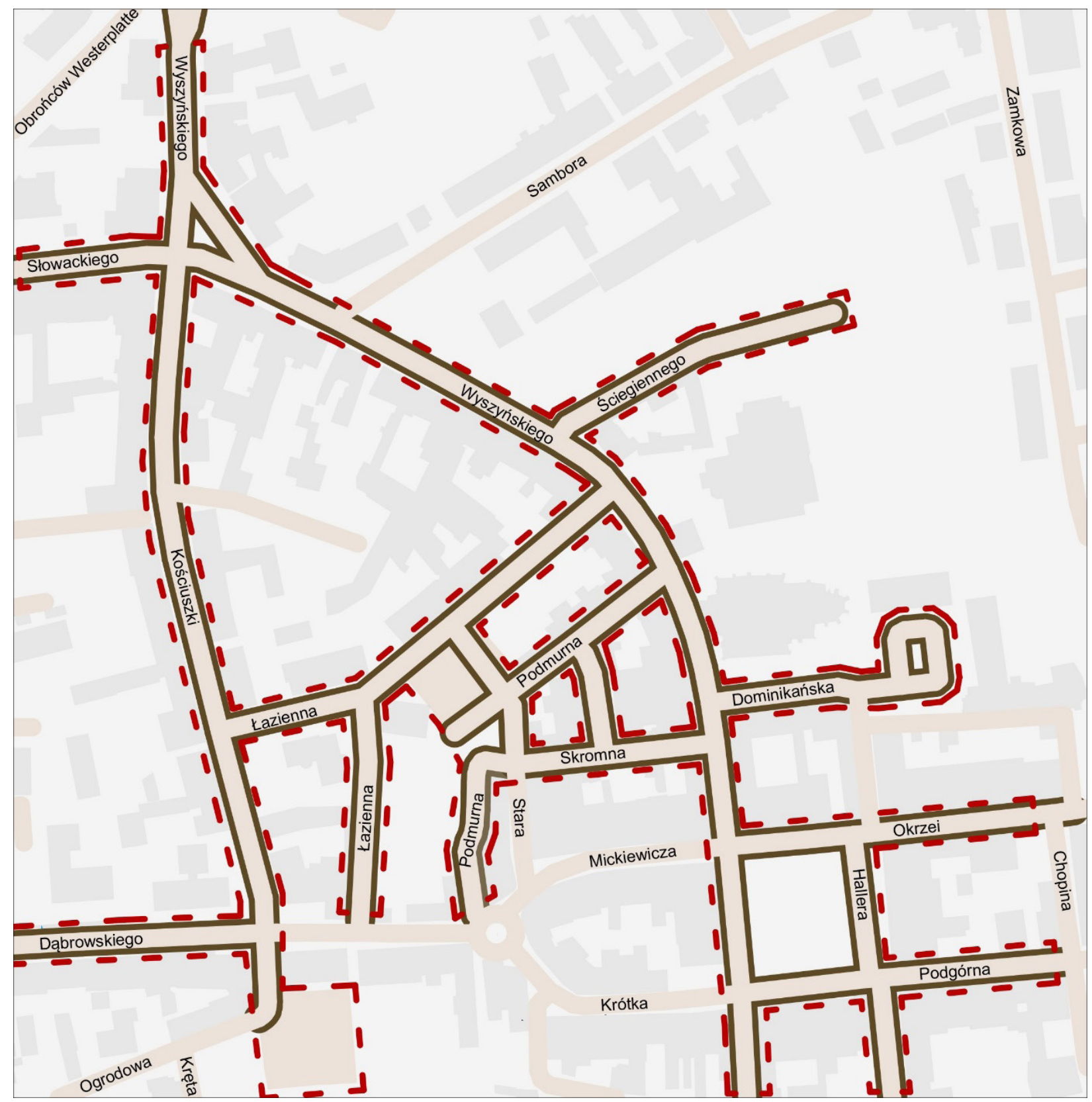

Ryc. 2. Planowany zasięg strefy płatnego parkowania na Starym Mieście w Tczewie.

Źródło: Opracowanie własne na podstawie: Urząd Miejski w Tczewie: Biuletyn Informacji Publicznej, 2021.

\section{Wyniki badań}

Przechodząc do części wynikowej opracowania w pierwszej kolejności starano się wskazać, w jakim celu i w jaki sposób zarówno mieszkańcy Tczewa, jak i przyjezdni, docierają na Stare Miasto. Jak pokazały wyniki badań, aż 37,8\% respondentów wybrało się na Stare Miasto na zakupy. Pozostałe kategorie były na tym tle wybierane znacznie rzadziej. Spośród ogółu badanych $17,2 \%$ wybrała się na Stare Miasto w celach rekreacyjnych, $14,5 \%$ pracuje na Starym Mieście, 11,5\% chciało skorzystać z usług typu urząd, notariusz, fryzjer, 5,9\% dociera tu do szkoły, 3,8\% do kawiarni lub restauracji, a 2,1\% w celu skorzystania z usług medycznych. Należy również odnotować fakt, iż zaledwie 6,2\% badanych zaznaczyło, iż ma tu swój dom, jednak zdecydowana większość osób mieszkających na co dzień w zespole staromiejskim i biorących udział w badaniu podała inny niż miejsce zamieszkania cel wizyty na tym terenie (ryc. 3).

Poza celem wizyty bardzo ważne było zdiagnozowanie, w jaki sposób ankietowani docierali do Starego Miasta. Biorąc pod uwagę generalnie duże przywiązanie polskiego społeczeństwa do samochodu, o sposób dotarcia na Stare Miasto zapytano w odniesieniu do konkretnego dnia, w którym przeprowadzono badanie 

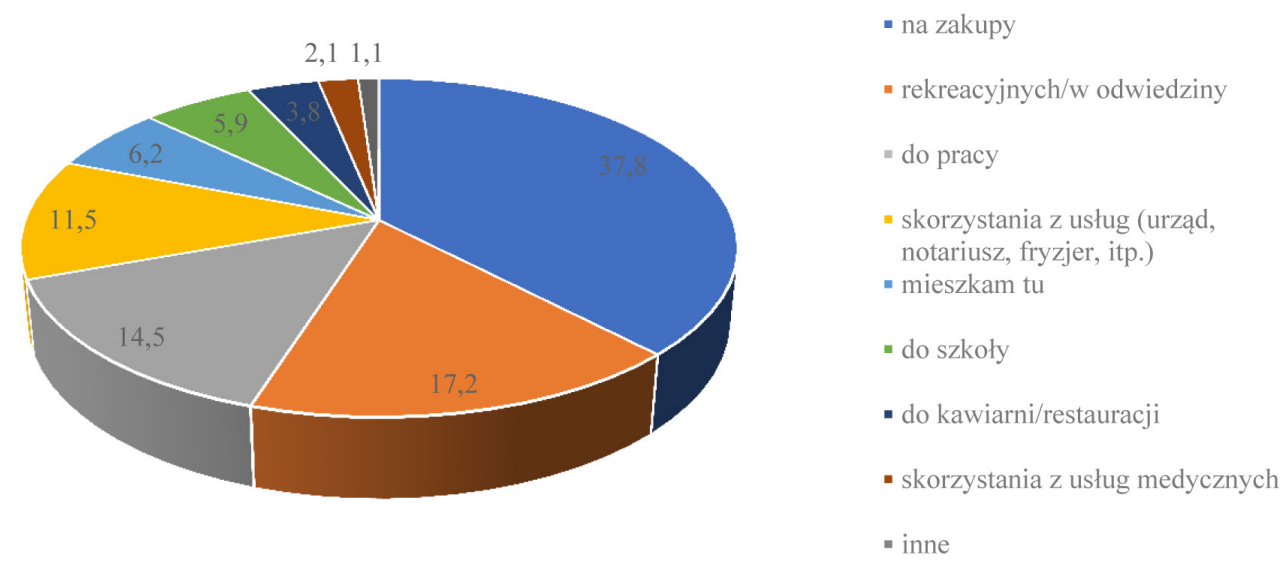

Ryc. 3. Struktura odpowiedzi na pytanie: „W jakich celach dotarł/a Pan/i na Stare Miasto?”

Źródło: Opracowanie własne na podstawie badań ankietowych (N = 373).

oraz do najczęstszych zachowań komunikacyjnych respondentów. Analiza tych dwóch pytań pokazała, że wyniki odpowiedzi były do siebie bardzo zbliżone. Ponad połowa badanych (52,8\% w kontekście dnia badania i 53,4\% w kontekście faktu, jak najczęściej badany dociera na Stare Miasto) docierała na Stare Miasto pieszo, co należy uznać za względnie satysfakcjonujący wynik. Jednak już co piąty badany (odpo-

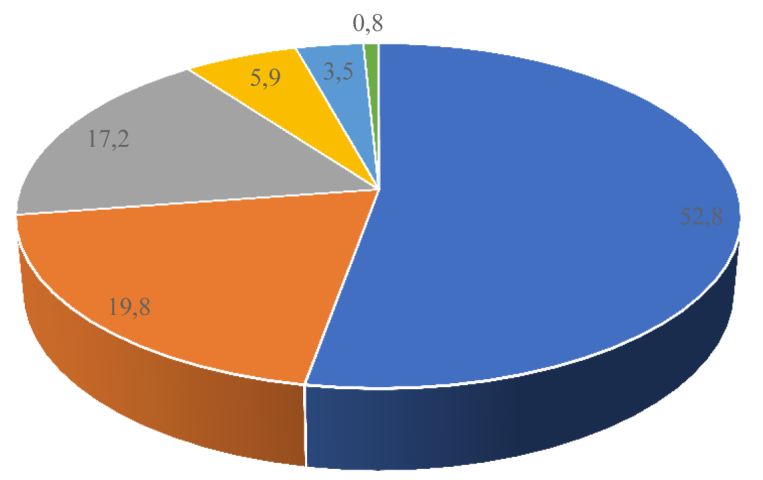

wiednio 19,8\% oraz 22,3\%) przyjechał na Stare Miasto jako kierowca, a dalsze ponad 5\% (odpowiednio 5,9\% i 5,4\%) było pasażerami. Tylko ok. 15\% ankietowanych przyjechało na Stare Miasto autobusem (odpowiednio $17,2 \%$ i $15,0 \%), 3,5 \%$ rowerem, a mniej niż $1 \%$ - na desce, hulajnodze lub rolkach (ryc. 4 i 5).

W dalszej kolejności prześledzono, jakie ograniczenia w ruchu lub parkowaniu samochodów są

Ryc. 4. Struktura odpowiedzi na pytanie: „Jak dziś dotarł/a Pan/i na Stare Miasto?"

Źródło: Opracowanie własne na podstawie badań ankietowych ( $\mathrm{N}=373)$.

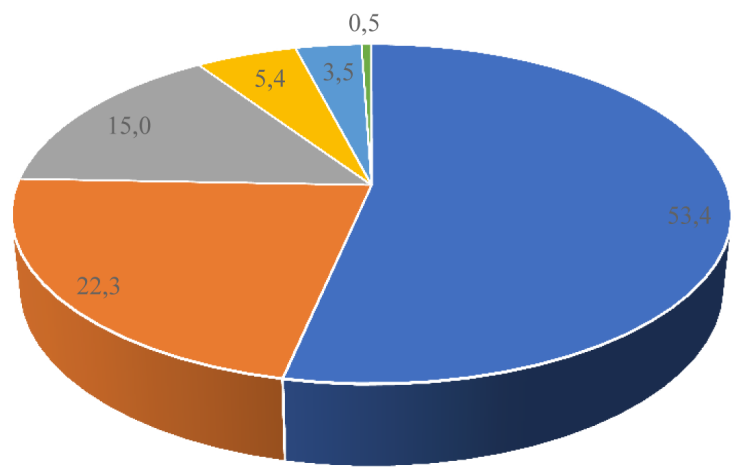

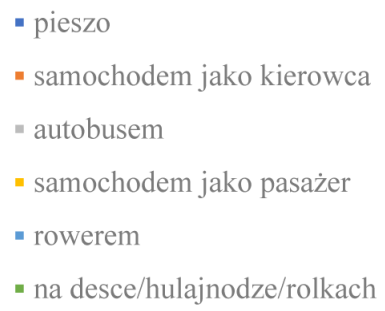

- pieszo

" autobusem

- samochodem jako pasażer

- na desce/hulajnodze/rolkach

Ryc. 5. Struktura odpowiedzi na pytanie: „Czym najczęściej (najwięcej razy) dociera Pan/i na Stare Miasto?”

Źródło: Opracowanie własne na podstawie badań ankietowych (N = 373). 
gotowi zaakceptować mieszkańcy i osoby korzystające z przestrzeni Starego Miasta. Pytania w tej części ankiety skierowano tylko do osób, które przybyły na Stare Miasto samochodem, zarówno jako kierowcy, jaki jako pasażerowie. Jak wykazano w trakcie badań ankietowych, aż 70,6\% badanych nie zrezygnowałoby z samochodu. Tylko mniej niż co trzeci badany byłby skłonny zrezygnować z samochodu, przy czym 14,7\% zdecydowałoby się chodzić pieszo, 5,5\% - korzystać $z$ autobusu, 1,8\% - jeździłoby rowerem, a mniej niż $1 \%$ - jeździłoby na desce, hulajnodze lub rolkach (ryc. 6).

Znacznie bardziej interesujące wyniki dało jednak pytanie dotyczące kwoty, którą ankietowany byłby w stanie zapłacić, aby móc zaparkować na Starym Mieście. Pomimo deklaracji, że ponad $2 / 3$ jeżdżących samochodem respondentów nie zrezygnowałaby z tego środka transportu, tylko 0,8\% badanych uznało, że zapłaciłoby każdą kwotę za miejsce parkingowe w obrębie zespołu staromiejskiego. Ponadto, 19,2\% respondentów byłoby skłonnych zapłacić 1 zł za pierwszą godzinę parkingu, $6,7 \%-1,5$ zł, 21,7\% - 2 zł, 5,0\% $-2,5$ zł, 10,8\% - 3 zł i 10,8\% - 3,5 zł (ryc. 7). W grupie osób, które uznały, że nie zrezygnują z samochodu w przypadku pojawienia się na Starym Mieście płatnych stref parkowania, 20,8\% byłoby skłonnych zapłacić 1 zł za pierwszą godzinę parkowania, 10,4\% - 1,5 zł, $23,4 \%-2$ złł, 5,2\% - 2,5 zł, 9,1\%- 3 zł, 7,8\% - 3,5 zł, $1,3 \%$ - każdą kwotę a 22,1\% - żadnej kwoty. Zatem byłyby one w stanie zapłacić nawet nieco mniejsze pieniądze za strefy płatnego parkowania niż osoby, które zadeklarowały, że przestawiłyby się na inne środki transportu.

Poza ograniczeniami związanymi z ewentualną zamianą samochodu na inny środek lokomocji lub opłatą za parking, korzystających z samochodu ankietowanych zapytano również, jaki dystans byliby skłonni pokonać, aby dotrzeć od miejsca parkingowego do punktu docelowego ich wizyty na Starym Mieście. Zgodnie z deklaracjami respondentów, zdecydowana większość z nich byłaby skłonna pokonać pieszo dystans ok. 5 min, tj. ok. 500 m (30,0\%) lub nawet większy niż $500 \mathrm{~m}$ (30,8\%). Tylko nieco poniżej 40\% badanych uznało, że jest w stanie pokonać dystans nieprzekraczający 4 min, w tym $11,7 \%$ - dystans do 1 min, tj. 100

Ryc. 6. Struktura odpowiedzi na pytanie: „Parkowanie zwiększa rotację pojazdów, a co za tym idzie częściej można znaleźć miejsce do parkowania. Czy w przypadku płatnego parkowania na Starym Mieście zrezygnowałby/aby Pan/i z dojazdów samochodem na Stare Miasto?" (pytanie adresowano tylko do osób, które przybyły na Stare Miasto samochodem).

Źródło: Opracowanie własne na podstawie badań ankietowych ( $\mathrm{N}=373)$.

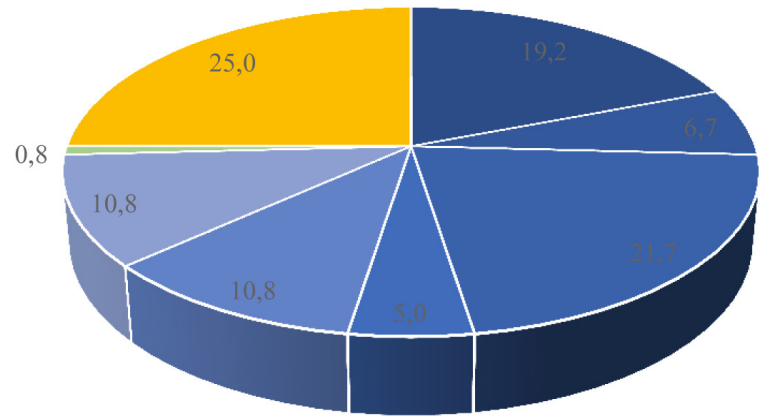

Ryc. 7. Struktura odpowiedzi na pytanie: „Jaka max. kwota za płatne parkowanie jest dla Pan/i akceptowalna?" (pytanie adresowano tylko do osób, które przybyły na Stare Miasto samochodem).

Źródło: Opracowanie własne na podstawie badań ankietowych ( $\mathrm{N}=373)$.

\section{- 1,0 zł za pierwszą godzinę \\ - 1,5 zł za pierwszą godzinę \\ - 2,0 zł za pierwszą godzinę \\ - 2,5 zł za pierwszą godzinę \\ - 3,0 zł za pierwszą godzinę \\ - 3,5 zł za pierwszą godzinę}

- Każda kwota, pod warunkiem możliwości zaparkowania na Starym Mieście

- Żadna 
m, 9,2\% - dystans do $2 \mathrm{~min}, \mathrm{tj} .200 \mathrm{~m}, 13,3 \%$ - dystans do $3 \mathrm{~min}, \mathrm{tj} .300 \mathrm{~m}$ i 5,0\% - dystans do $4 \mathrm{~min}, \mathrm{tj} .400$ $\mathrm{m}$ (ryc. 8). Biorąc pod uwagę miejsce zamieszkania, najdłuższy dystans zadeklarowały osoby mieszkające poza Tczewem, w dalszej kolejności mieszkańcy Tczewa, ale spoza zespołu staromiejskiego, a najmniejszy dystans - mieszkańcy Starego Miasta (ryc. 9).

Ostatnią kwestią, którą podjęto w niniejszym badaniu jest zwrócenie uwagi na wpływ stref płatnego parkowania na gospodarkę i kondycję lokalnego biznesu. Jest to z całą pewnością sprawa, która budzi wiele obaw społecznych. W tym kontekście zapytano respondentów, ile mniej więcej pieniędzy wydali na Starym Mieście $w$ dniu badania ankietowego. Jak wskazują odpowiedzi, najwyższy odsetek badanych, czyli aż 38,9\% osób, nie wydało na Starym Mieście nic. Prawie co trzeci ankietowany wydał do 50 zł (32,7\%), natomiast od $50 \mathrm{zł}$ do $100 \mathrm{zł}$ wydało $15 \%$ badanych. Tylko $8 \%$ respondentów wydało od 100 zł do 200 zł, $3,8 \%$ od 200 zł do 500 zł i jedynie $1,6 \%$ osób wydało więcej niż 500 zł (ryc. 10).
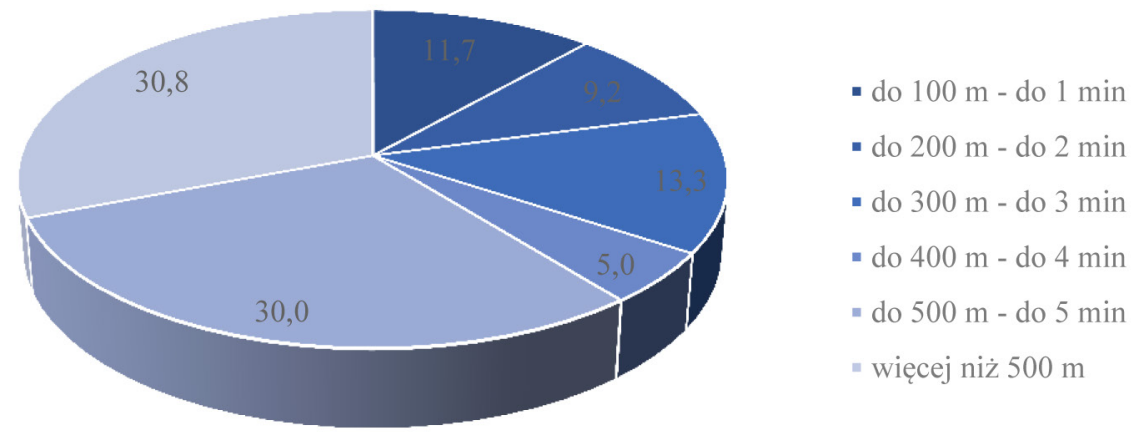

Ryc. 8. Struktura odpowiedzi na pytanie: „W przypadku zamknięcia części ulic dla ruchu samochodowego i udostępnienia pieszym i rowerzystom, jaką max. odległość jest Pan/i w stanie pokonać od parkingu do sklepu/restauracji/punktu usługowego na Starym Mieście?" (pytanie adresowano tylko do osób, które przybyły na Stare Miasto samochodem).

Źródło: Opracowanie własne na podstawie badań ankietowych ( $\mathrm{N}=373)$.

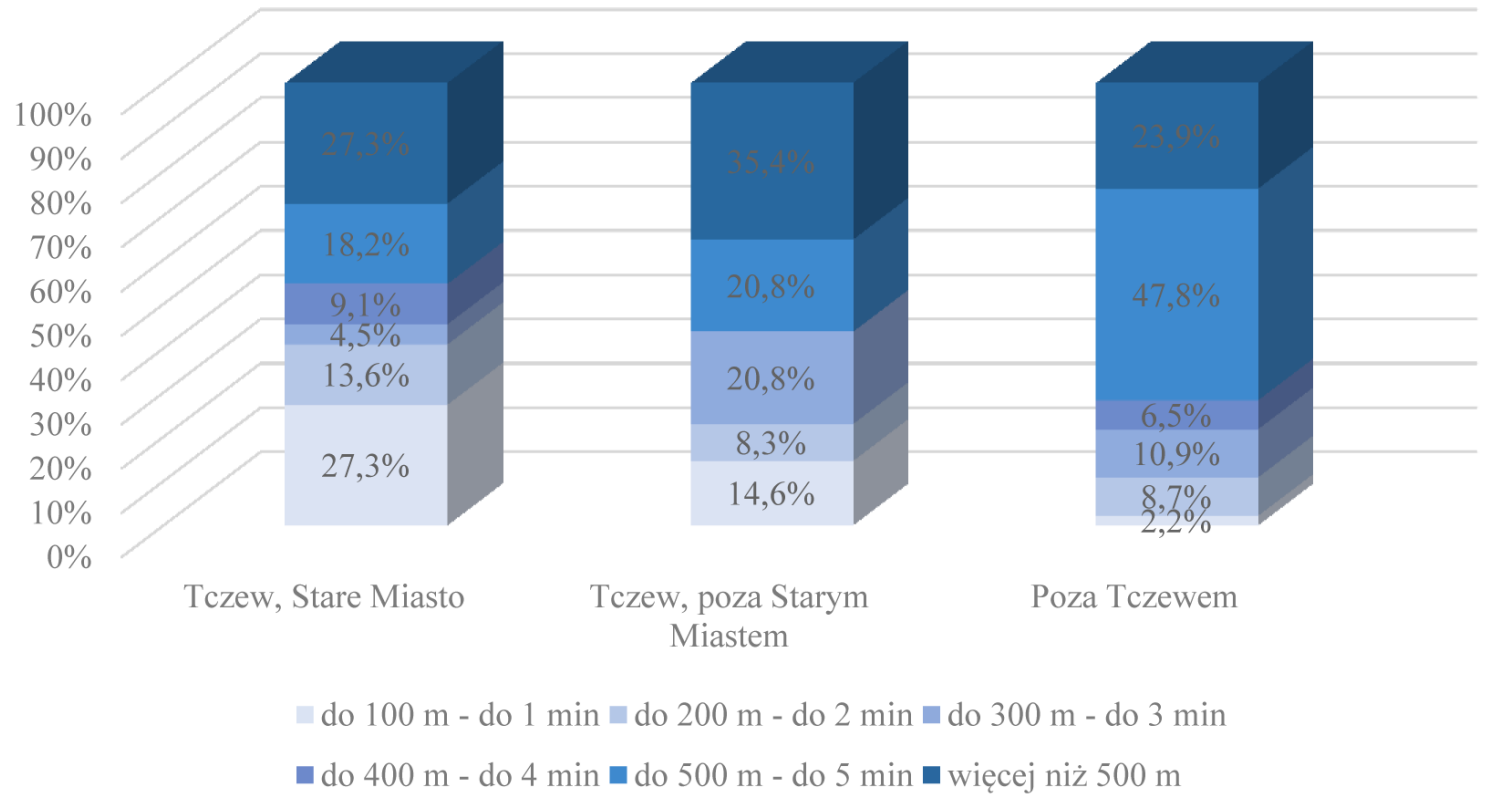

Ryc. 9. Struktura odpowiedzi na pytanie: „W przypadku zamknięcia części ulic dla ruchu samochodowego i udostępnienia pieszym i rowerzystom, jaką max. odległość jest Pan/i w stanie pokonać od parkingu do sklepu/restauracji/punktu usługowego na Starym Mieście?" vs. „Miejsce zamieszkania”.

Źródło: Opracowanie własne na podstawie badań ankietowych ( $\mathrm{N}=373)$. 


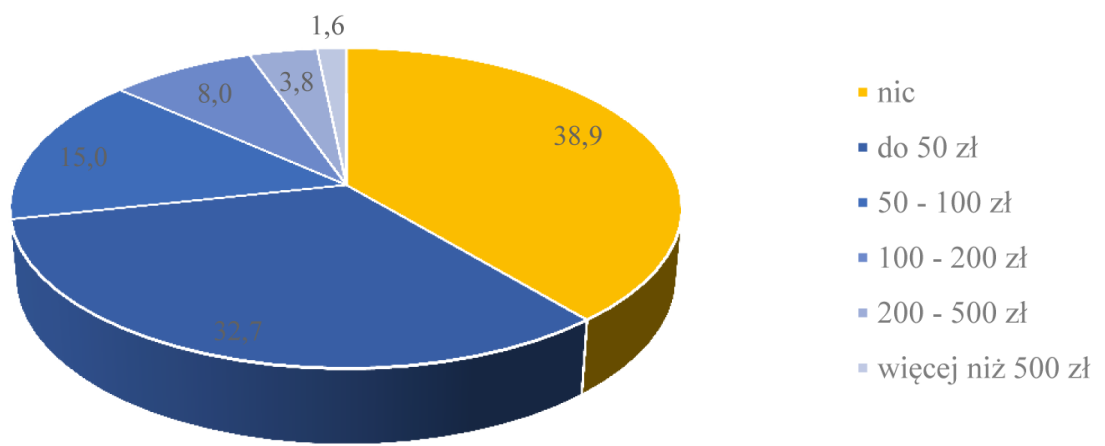

Ryc. 10. Struktura odpowiedzi na pytanie: „Ile mniej więcej wydał/a Pan/i dziś na Starym Mieście?”

Źródło: Opracowanie własne na podstawie badań ankietowych ( $\mathrm{N}=373)$.

W dalszej kolejności odpowiedzi uzyskane na pytanie rozpatrzono uwzględniając miejsce zamieszkania respondentów. Wydzielono w ten sposób trzy grupy - osoby mieszkające na Starym Mieście Tczewa, osoby mieszkające poza Starym Miastem w Tczewie, a także osoby przyjezdne, spoza Tczewa. Co istotne, najwięcej pieniędzy wydały osoby przyjezdne, mieszkające poza Tczewem. Aż 16\% z nich w dniu badania wydało na Starym Mieście ponad 100 zł (8\% wydało od 100 zł do 200 zł, 5,3\% od 200 zł do 500 zł i 2,7\% więcej niż $500 \mathrm{zł}), 12 \%$ ankietowanych wydało od 50 zł do $100 \mathrm{zł}$, natomiast co czwarty respondent wydał do 50 zł. Równocześnie jest to grupa społeczna, w której obserwujemy najwyższy odsetek osób, które nie wydały nic (46,7\%). Zdecydowanie mniej pieniędzy wydali mieszkańcy Tczewa, zarówno ci mieszkający na Starym
Mieście, jak i poza nim. Relatywnie wysokie wydatki respondentów mieszkających na Starym Mieście należy wiązać z faktem, że jest to nie tylko miejsce ich zamieszkania, ale także codziennych zakupów. Świadczy o tym wydawana przez nich kwota. W dniu badania co trzeci mieszkaniec Starego Miasta nie wydał więcej niż 50 zł $(32,4 \%)$, natomiast prawie co czwarty więcej niż 100 zł (23,0\%). Co trzeci respondent $(31,7 \%)$ nie wydał nic, natomiast więcej niż 100 zł wydało jedynie $12,9 \%$ badanych. Jeszcze inaczej przedstawiają się wydatki osób mieszkających w Tczewie, jednak poza Starym Miastem. Ich wydatki zwykle nie przekraczały 50 zł (43,8\% respondentów nie wydało nic; $33,6 \%$ wydało do 50 zł). Jedynie $10,2 \%$ badanych wydało od 50 zł do 100 zł, a więcej niż 100 zł - 12,5\% badanych (ryc. 11).

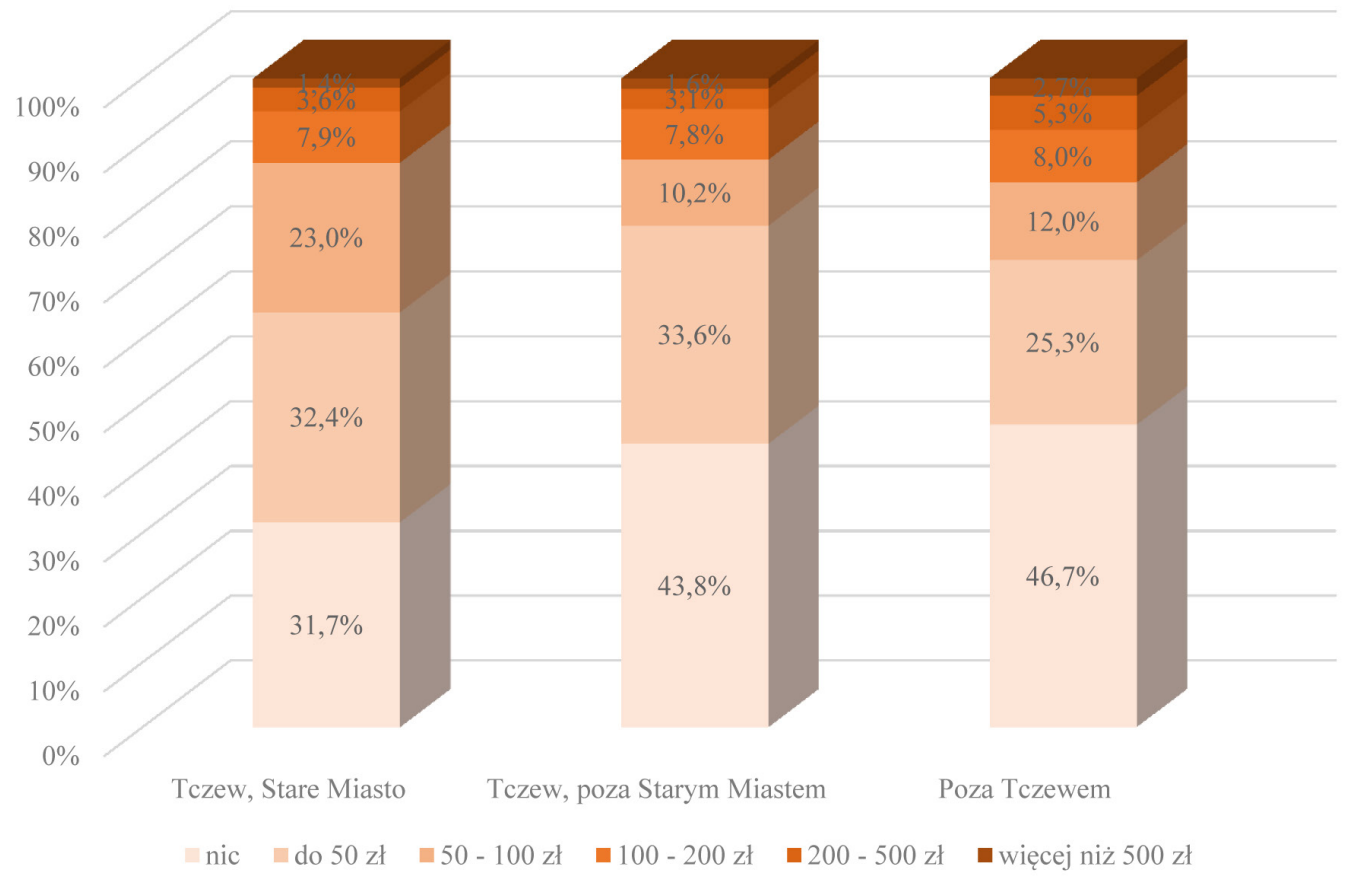

Ryc. 11. Struktura odpowiedzi na pytanie: „Ile mniej więcej wydał/a Pan/i dziś na Starym Mieście?" vs. "Miejsce zamieszkania". 
Z uwagi na obawy lokalnych przedsiębiorców dotyczące negatywnego wpływu wprowadzenia stref płatnego parkowania na Starym Mieście na gospodarkę i kondycję lokalnego biznesu, pytanie o wydaną przez respondentów kwotę rozpatrzono również dzieląc respondentów zgodnie ze środkiem transportu, którym dotarli na Stare Miasto. Jak wskazują odpowiedzi, najwyższy odsetek respondentów, którzy wydali w dniu badania ponad 100 zł, stanowia rowerzyści (30,8\%), w tym połowa z nich wydała od 100 zł do 200 zł, natomiast co czwarty od 200 zł do 500 zł i również co czwarty więcej niż 500 zł. Znacznie niższy odsetek osób, które wydały ponad 100 zł stanowią pasażerowie samochodów (18,1\%), kierowcy samochodów (17,6\%), osoby podróżujące autobusem (11\%) oraz chodzące pieszo (10,9\%). Przypatrując się z kolei wydzielonym grupom w kontekście odsetka osób, które nic nie wydały na Starym Mieście w dniu badania, należy zauważyć, że dominowali badani, którzy dotarli tu na desce/hulajnodze/rolkach (66,7\%), następnie osoby, które przyjechały samochodem jako kierowcy (47,3\%), autobusem (45,3\%), samochodem jako pasażerowie (40,9\%). Relatywnie najmniej takich osób odnotowano wśród osób, które przybyły na Stare Miasto pieszo (33,5\%) oraz rowerem (30,8\%) (ryc. 12).

\section{Wnioski}

Wprowadzenie ograniczeń w ruchu samochodów, w tym także strefy płatnego parkowania ma za zadanie poprawić jakość przestrzeni, szczególnie Starego Miasta, czy szeroko rozumianego centrum. Jest to niezwykle istotne także w średnich i małych miastach, w których do tej pory nie wprowadzano takich ograniczeń, pozostawiając parkowanie $w$ tej przestrzeni bez kontroli.

Uzyskane wyniki pokazują, że istnieje duży potencjał dla wprowadzania ograniczeń dla ruchu i parkowania pojazdów. Jak wykazano w pracy na przykładzie Tczewa, przestrzeń średniego miasta, głównie ze względu na zwarty charakter i krótkie dystanse między celami podróży, sprzyja docieraniu pieszo lub rowerem do centrum miasta. Przeprowadzone badanie dostarczyło przede wszystkim dowodu, że Stare Miasto w Tczewie (jeszcze przed wprowadzeniem ograniczeń i opłat dla samochodów) jest odwiedzane głównie przez osoby, które docierają do tego miejsca pieszo. Na ten sposób dotarcia do centrum wskazał co drugi respondent. Samochodem natomiast, jako kierowca lub pasażer, przybywa średnio co czwarty lub co trzeci z badanych. Wynik ten wskazuje, że ewentualne zmiany

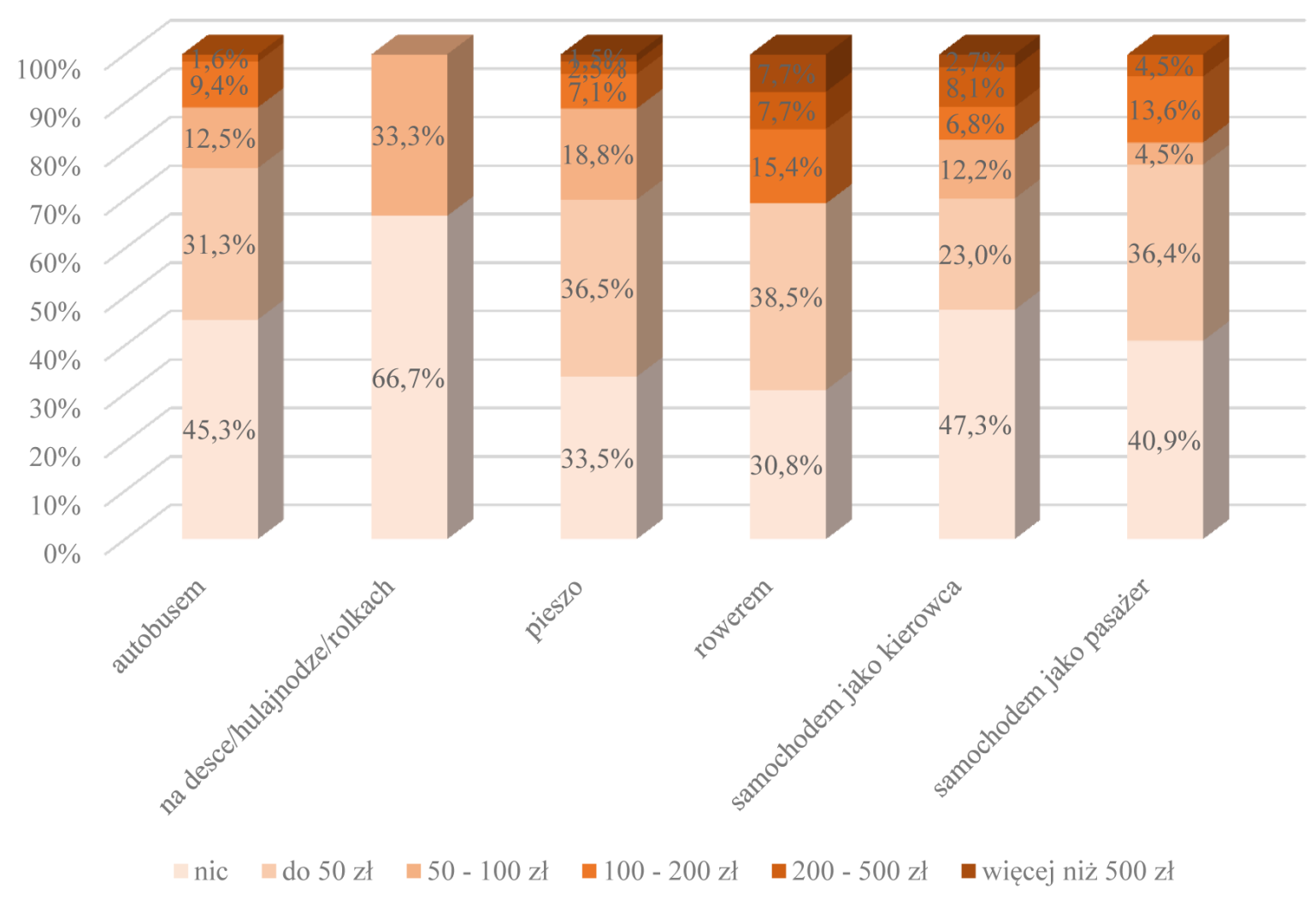

Ryc. 12. Struktura odpowiedzi na pytanie: „Ile mniej więcej wydał/a Pan/i dziś na Starym Mieście?" vs. "Jak dziś dotarł/a Pan/i na Stare Miasto?"

Źródło: Opracowanie własne na podstawie badań ankietowych (N = 373). 
w zasadach ruchu i parkowania dla samochodów nie powinny w znacząco negatywny sposób wpłynąć na zainteresowanie mieszkańców tą częścią miasta. Oczywiste zatem staje się udowodnione w tym badaniu stwierdzenie, że wprowadzenie ograniczeń w ruchu samochodów nie spowoduje znacznego odpływu osób, które dotychczas tam docierały. Wprowadzenie ograniczeń w ruchu samochodów oraz stref płatnego parkowania w miastach podyktowane będzie zatem dbałością o osoby najliczniej korzystające z tej przestrzeni - osoby chodzące pieszo.

W uzyskanych wynikach widoczny jest także wysoki poziom akceptacji dla zwiększenia dystansu dotarcia do celu w przypadku wyłączenia pewnych ulic z ruchu kołowego oraz wprowadzenia opłat za parkowanie. Uzyskany wynik potwierdza, że mieszkańcy miasta nie postrzegają odległości w mieście jako bariery w przemieszczaniu się.

Zebrane w badaniu wyniki pozwalają stwierdzić, że wprowadzenie strefy płatnego parkowania nie wpłynie w negatywny sposób na istniejące tam działalności gospodarcze. Wykazano, że piesi i rowerzyści wydają mniejsze kwoty, ale stanowią większą grupę wydającą pieniądze na Starym Mieście niż użytkownicy samochodów.

Ograniczeniem w tym badaniu może być uchwycenie sytuacji chwilowej - zbadano wyłącznie wydatki w dniu prowadzenia badania. Ustalenie częstości zakupów na Starym Mieście wymagałoby zatem prowadzenia cyklicznych badań na tej samej grupie osób. Wprowadzenie ograniczeń w ruchu samochodów oraz opłat za parkowanie ma na celu zwiększenie rotacji samochodów na parkingach, a w związku z tym zwiększenie liczby osób, które skorzystają z oferty Starego Miasta. Jest to kolejny argument, który potwierdza, że prowadzone na Starym Mieście sklepy i usługi mogą skorzystać po wprowadzeniu strefy płatnego parkowania.

Przeprowadzone badanie pozwoliło zatem wykazać, że:

- mieszkańcy Tczewa docierają na Stare Miasto głównie pieszo,

- 3/4 osób korzystających z przestrzeni Starego Miasta jest gotowe zaakceptować opłaty za parkowanie pojazdów w tym miejscu,

- ograniczenie dostępu samochodem do Starego Miasta nie powinno znacząco wpłynąć na działalności gospodarcze prowadzone w tym miejscu.

Przyjęte w badaniu metody pozwoliły na udzielenie odpowiedzi na postawione pytania badawcze i zdają się być właściwe szczególnie w małych i średnich miastach o wyraźnie zarysowanej części centralnej (najczęściej o charakterze staromiejskim), zwartej strukturze i niewielkich odległościach między celami mobilności mieszkańców.
Wdrażanie ograniczeń w ruchu samochodów, ze względu na wysoki poziom motoryzacji, może być uznawane za kontrowersyjną decyzję. Dlatego też wprowadzenie takiego rozwiązania powinno być poprzedzone szeroko prowadzonymi konsultacjami, w ramach których wyjaśniane byłyby wątpliwości przeciwników takich rozwiązań oraz pokazywane cele działania oraz możliwe do uzyskania korzyści. Wdrażając strefę płatnego parkowania należy również pamiętać o mieszkańcach Starego Miasta, dla których należy zwiększyć dostępność parkowania poprzez wprowadzenie abonamentów i niższych cen za pozostawianie pojazdu w pobliżu miejsca zamieszkania. Niniejsza praca dostarcza dowodów na dużą akceptację możliwości wdrażania strefy płatnego parkowania w mieście średniej wielkości. Samorządy decydujące się na wprowadzenie ograniczeń ruchu samochodów powinny mieć na uwadze głównie korzyści dla mieszkańców, które mogą przynosić takie działania.

\section{Podziękowanie}

Autorzy opracowania chcieliby szczególnie podziękować uczniom Zespołu Szkół Budowlanych i Odzieżowych w Tczewie, klas o profilu logistyka i o profilu spedycja, za szczególne zaangażowanie i pomoc w realizacji badania ankietowego.

\section{Piśmiennictwo}

Arancibia D., Farber S., Savan B., Verlinden Y., Lea N.S., Allen J., Vernich L., 2019, Measuring the Local Economic Impacts of Replacing On-Street Parking With Bike Lanes, Journal of the American Planning Association, 85(4), 463-481. DOI: 10.1080/01944363.2019.1638816.

Ardeshiri A., Safarighouzhdi F., Hossein Rashidi T., 2021, Measuring willingness to pay for shared parking, Transportation Research Part A: Policy and Practice, 152, 186-202. DOI: 10.1016/j.tra.2021.08.014.

Brzeziński, A., Dybicz T., 2013, Problemy funkcjonowania strefy płatnego parkowania w centrum miasta, Zeszyty Naukowo-Techniczne SITK RP, Oddział w Krakowie, 1(100), 25-36.

Duda-Wiertel U., Szarata A., 2019, The analysis of transport-related behaviours of drivers in highly occupied paid parking zones, Advances in Transportation Studies, 47, 35-48. DOI: 10.4399/9788255233483.

Guo Z., McDonnell S., 2013, Curb parking pricing for local residents: An exploration in New York City based on willingness to pay, Transport Policy, 30, 186-198. DOI: 10.1016/j.tranpol.2013.09.006

Kiciński M., Żmuda-Trzebiatowski P., 2018, Strefy płatnego parkowania w małych miastach. Analiza rozwiązań na przykładzie Środy Wielkopolskiej, Transport Miejski i Regionalny, 9, 39-44. 
Marsden G., 2006, The evidence base for parking policies - a review, Transport Policy, 13(6), 447-457. DOI: 10.1016/ j.tranpol.2006.05.009.

Mingardo G., van Wee B., Rye T., 2015, Urban parking policy in Europe: A conceptualization of past and possible future trends, Transportation Research Part A - Policy and Practice, 74, 268-281. DOI: 10.1016/j.tra.2015.02.005.

Rietveld P., Koetse M., 2008, Paid parking in cities: Regulating parking demand and consequences for the retail sector, Studies in Regional Science, 38(1), 215-225. DOI: 10.2457/srs.38.215.

Rietveld P., Koetse M., Woudenberg S., 2002, Parking in cities: how essential is parking for healthy central shopping areas? Nederlandse Geografische Studies, 29-46.

Scheiner J., Faust N., Helmer J., Straub M., Holz-Rau C., 2020, What's that garage for? Private parking and on-street parking in a high-density urban residential neighbourhood, Journal of Transport Geography, 85, 102714. DOI: 10.1016/j.jtrangeo.2020.102714.

Shoup D., 2005, The high costs of free parking, American Planning Association, Chicago.

Sklorz J., 2013, O strefach płatnego parkowania dobrze i krytycznie - na podstawie wieloletnich doświadczeń ich funkcjonowania, problemów projektowania i wdrażania - w pytaniach i odpowiedziach, Zeszyty Naukowo-Techniczne Stowarzyszenia Inżynierów i Techników Komunikacji w Krakowie, 1(100), 261-268.
Sztabinski F., 2009, Bike lanes, on-street parking and business: A study of Bloor Street in Toronto's Annex Neighbourhood, Clean Air Partnership, Toronto.

Szymańska D., 2013, Geografia osadnictwa, PWN, Warszawa. Środa-Murawska S., 2019, Rozwój oparty na sektorze kultury. Doświadczenia średnich miast w Polsce, Wydawnictwo Naukowe Uniwersytetu Mikołaja Kopernika, Toruń.

Urząd Miejski w Tczewie, 2021a, https://wrotatczewa.pl/ ilu-nas-jest/

Urząd Miejski w Tczewie, 2021b, https://wrotatczewa.pl/ zainwestuj-w-tczewie/dlaczego-warto/

Urząd Miejski w Tczewie: Biuletyn Informacji Publicznej, 2021, https://bip.tczew.pl/wiadomosci/archiwum/1138/ wiadomosc/593014/projekt_uchwaly_na_sesje_rady_ miejskiej_w_tczewie_w_dniu_28_pazd

Urząd Miejski w Tczewie: Tczew - Miasto dla Rowerów, 2020, https://rower.tczew.pl/liczba-samochodow-w-tczewie-2005-2018/

van Ommeren J., Wentink D., Dekkers J., 2011, The real price of parking policy, Journal of Urban Economics, 70(1), 25-31. DOI: 10.1016/j.jue.2011.02.001

von Schneidemesser D., Betzien J., 2021, Local Business Perception vs. Mobility Behavior of Shoppers: A Survey from Berlin. Transport Findings, June. DOI: 10.32866/01c.24497

Yan X., Levine J., Marans R., 2019, The effectiveness of parking policies to reduce parking demand pressure and car use, Transport Policy, 73, 41-50. DOI: 10.1016/j. tranpol.2018.10.009. 